\title{
Coronavirus: a clinical update of Covid-19
}

Mateus da Silveira Cespedes ${ }^{1}$

(iD) José Carlos Rosa Pires de Souza²

1. Acadêmico de medicina da Universidade Estadual de Mato Grosso do Sul, Campo Grande, MS, Brasil 2. PhD em saúde mental, psiquiatra docente do curso de Medicina da Universidade Estadual de Mato Grosso do Sul, Campo Grande, MS, Brasil

http://dx.doi.org/10.1590/1806-9282.66.2.116

\section{SUMMARY}

INTRODUCTION: A covid-19 pandemic decreed by WHO has raised greater awareness of it.

EPIDEMIOLOGY: The infection reached the mark of 350,000 patients in 33 countries and affected as comorbidities the presence of comorbidities and advanced age.

TRANSMISSIBILITY: The transmissibility calculated so far is similar to the H1N1 epidemic, but with lower mortality rates.

PHYSIOPATHOLOGY: The SARS-CoV-2 virus, of the Coronaviridae family, has the capacity for cellular invasion through the angiotensin-converting enzyme 2 does not have a lower respiratory epithelium and in the cells of the small intestine mucosa.

CLINICAL MANIFESTATIONS: a presentation can be divided into mild (fever, fatigue, cough, myalgia, and sputum) and severe (cyanosis, dyspnoea, tachypnea, chest pain, hypoxemia and need for clinical measurement) and has an estimated estimate of $2 \%$.

DIAGNOSIS: allows the detection of viral load in CRP-TR of patients with high clinical suspicion.

TREATMENT: based on supportive measures and infection control. In severe cases, the use of medications such as hydroxychloroquine and azithromycin or medication can be promising. Take care to avoid the use of corticosteroids. There are no restrictions on the use of resources and ACEIS / ARBS.

KEYWORDS: coronavirus, covid-19, SARS-CoV-2, pandemic, update.

\section{INTRODUCTION}

Originally discovered in poultry in the 1930s, several coronaviruses cause respiratory, gastrointestinal, liver, and neurological disease in animals. Only seven coronaviruses are known to cause disease in humans. Four of these (229E, OC43, NL63, and HUK1) more often cause symptoms of a common cold. On rare occasions, there may be a severe infection of the lower respiratory tract, such as pneumonia, especially in children, the elderly, and immunocompromised patients. ${ }^{1}$
The three coronaviruses that cause the most severe respiratory infection in humans, sometimes even fatal, are considered zoonoses and are described below:

SARS-CoV-2 is the new coronavirus identified on 31/12/2019 as the etiological agent of the disease caused by coronavirus 2019 (Covid-19) described in Wuhan, China.

Mers-Cov was identified in 2012 as the cause of the Middle East Respiratory Syndrome (MERS).

DATE OF SUBMISSION: 24-Mar-2020

DATE OF ACCEPTANCE: 26-Mar-2020

CORRESPONDING AUTHOR: Mateus Cespedes

Av. Dom Antônio Barbosa, 4155 - Vila Santo Amaro - Campo Grande, Mato Grosso do Sul - Brasil - 79115-898

Tel: (67) 3901-4621

E-mail: mateus.cespedes@hotmail.com 
SARS-CoV was identified in 2002 as the cause of an outbreak of Severe Acute Respiratory Syndrome (SARS).

It is believed that Covid-19 (SARS-CoV-2) originated in Chiroptera mammals (bats), since they have been reported to a local animal trade in Wuhan, and due to its close genetic similarity to infectious coronavirus in this genre. ${ }^{2}$

\section{EPIDEMIOLOGY AND RISK FACTORS}

Only 71 days after the discovery of covid-19 (and 59 days from its genetic sequencing), on 11/03/2020, The World Health Organization declared a pandemic. A total of 33 countries have registered covid-19 cases, with at least 350,000 cases and 15,000 deaths ${ }^{2}$. A large global economic impact has been estimated due to the saturation of health systems and quarantine state, with an expected GDP of $24 \%$ recession in the most affected quarter in the US.

The average age of infected individuals ranges between 49 and 56 years, and the conditions in rare in individuals younger than 20 years (children, in general, are asymptomatic) ${ }^{3}$. Severity increases with age, and the mean age of deaths in Italy (the second epicenter of the pandemic) is 79.5 years.

Among the known risk factors for severe symptomatic presentation are cardiovascular (hypertension) and pulmonary (smoking, asthma) comorbidities and advanced age (over 60 years) ${ }^{3}$.

\section{TRANSMISSIBILITY}

Transmissibility is mainly by droplets - close interpersonal contact (less than 2m - 6 feet - for a prolonged time) - and fomites ${ }^{3}$. Studies in the USA with 445 contacts of infected individuals found a rate of social contagion of $0.45 \%$. Fecal-oral transmission is possible (due to the presence of ACE2 in the gastrointestinal tract and the presence of positive RT-PCR in stool samples); however, it has yet to be documented ${ }^{4}$.

A very important quantification of viral transmissibility is the basic reproduction number, which is usually denoted by $R_{0}$ (pronounced "R-naught"). The epidemiological definition of $R_{0}$ is the average number of people who contract a disease from a contagious person. It applies specifically to a population of people who previously were free of infection and were not vaccinated. There are three possibilities for the potential spread or decline of disease, depending on the value of $R_{0}$ :
If $R_{0}$ is less than 1 , each existing infection generates less than 1 new infection. In this case, the disease will decrease and eventually disappear.

If $R_{0}$ is equal to 1 , the disease will remain alive, but there will be no epidemic.

If $R_{0}$ is greater than 1 , the cases will grow exponentially and cause an epidemic or even a pandemic.

As far as we currently know, the $R_{0}$ value calculated for $2019-n C o V$ is significantly greater than 1 . The preliminary estimate of a 1.4-2.5 $R_{0}$ was presented on the WHO declaration about the 2019-nCoV outbreak on January 23, 2020. Studies had estimated the average $R_{0}$ for 2019-nCoV in the initial stage of the outbreak ranging from 3.3 to 5.5 (likely lower than 5 , but above 3 with increased rate), which was slightly higher than those of SARS-CoV $\left(R_{0}: 2-5\right)$, indicating that $72-75 \%$ of transmissions must be avoided to stop the growing trend. In contrast, previous studies had suggested that the $R_{0}$ for MERS-CoV is less than 1 , which means that it is unlikely to cause a pandemic. Super-spreading events have been implicated in the transmission of 2019-nCoV, as was the case with SARS-CoV and MERS$\mathrm{CoV}$, but its relative importance remains unclear, and it is difficult to trace the super-spreaders ${ }^{1}$. In addition, $R_{O}$ can change seasonally according to climate or annual gatherings $\mathbf{1}$.

Transmissibility seems to be reduced in hot and humid climates.

The table 1 compares the current major contagious diseases and covid-19 regarding mortality and $R_{0}^{1,3}$.

\begin{tabular}{l|l|l} 
Virus & Case Fatality Rate $\%$ & $R_{0}$ \\
\hline 2019-nCoV & 3 & $1.4-5.5^{\mathrm{a}}$ \\
\hline SARS-CoV & 10 & $2-5$ \\
\hline MERS-CoV & 40 & $<1$ \\
\hline Avian H7N9 (2013) & 40 & $<1$ \\
\hline H1N1 (2009) & 0.03 & $1.2-1.6$ \\
\hline H1N1 (1918) & 3 & $1.4-3.8$ \\
\hline Measles Virus & 0.3 & $12-18$ \\
\hline Rhinovirus & $<0.01$ & 6 \\
\hline Ebola Virus & 70 & $1.5-2.5$ \\
\hline HIV & $80^{\text {b }}$ & $2-4$ \\
\hline Small Pox Virus & 17 & $5-7$ \\
\hline a - WHO: 1.4-2.5; S. Zhao et al.: $3.3-5.5 ; ~ J . ~ R e a d ~ e t ~ a l .: ~ 3.6-4.0 ; ~$ & M. Shen et al.: 4.5-4.9. \\
b - Without therapy & \multicolumn{2}{l}{}
\end{tabular}

\section{PHYSIOPATHOLOGY}

It has been reported that the coronaviruses, including covid-19, have their mechanism of infection by binding to the ACE2 (angiotensin-converting enzyme 
2) protein. Notably, ACE2 is abundantly present in humans in the epithelia of the lung and small intestine, and the coronaviruses can infect the upper respiratory and gastrointestinal tracts of mammals.

Studies indicate that the viral load detected in asymptomatic patients was similar to that found in symptomatic patients; however, the viral loads in patients with serious diseases were higher than those of patients with mild to moderate presentations. In addition, higher viral loads were detected in the nasal mucosa than in the oropharyn $x^{4}$. This suggests the effectiveness of an upper swab of the nasal mucosa, which presents less risk to the professional in charge of sample collection.

The incubation period ranges from 2 to 14 days (average of 5.2 days) ${ }^{5}$. The average time between the first symptoms and the development of acute respiratory distress syndrome (ARDS) is 8 days $^{6}$. A possible explanation for such rapid and serious deterioration in the cytokine release syndrome (CRS), or 'cytokine storm', an overproduction of immune cells and cytokines, which leads the system of multiple organs to fail and causes fatal damage to the tissues of the lungs, kidneys, and heart.

\section{CLINICAL PRESENTATIONS}

It is estimated that most individuals are asymptomatic or present only mild symptoms (85\%), including fever, fatigue, cough, myalgia, and sputum. There may be anosmia (initial symptom), headache, odynophagia, and runny nose. Severe cases (15\%) may include chest pain, dyspnea, cyanosis, tachypnea, signs of respiratory distress, hypotension, decompensation of underlying diseases, and lymphopenia, which must be treated in a hospital bed. RR $>30 \mathrm{bpm}$, SatO $2<93 \%$, $\mathrm{PaO} 2 / \mathrm{FiO} 2<300$ were indicators of poor prognosis and progression for mechanical ventilation (risk factors for mechanical ventilation: hypertension, diabetes mellitus, and age over 65 years). The mortality rate is around $2.9 \%$ (95\% CI 1,4-4,3\%), lower than SARS (10\%) ${ }^{6}$.

In severely immunosuppressed patients (transplanted), the initial presentation may be gastrointestinal (diarrhea and fever), progressing to respiratory involvement in $48 \mathrm{~h}^{7,8}$.

The most common finding on computed tomography scans of the chest in patients was ground-glass opacity nodules with peripheral and lowe-lobe bilateral involvement. Such findings may occur even in asymptomatic patients, but are more common in patients with covid-19-related pneumonia. The presence of a fine fibrotic layer (fine reticular opacities) indicates a good prognosis of the disease, with progression in remission ${ }^{6}$.

Convalescence lasts for 1 to 3 weeks for mild cases and from 2 to 6 weeks for severe cases. ${ }^{9}$

\section{DIAGNOSIS}

Clinical suspicion is based on the presence of fever and respiratory symptoms (cough, dyspnea). The presence of compatible epidemiology (contact with a suspected or confirmed case, travel to an endemic location in the previous 14 days) increases suspicion of covid-19 at the expense of other respiratory syndromes and should be an indication for a RT-PCR test. ${ }^{6}$

The diagnosis is possible through a positive RT-PCR or the presence of high clinical suspicion (compatible clinical signs + favorable epidemiology) associated with a CT scan with bilateral peripheral glass opacities of the lower lobes. ${ }^{9}$

\section{TREATMENT}

The treatment is supportive (antipyretics and hydration). General measures such as oxygen supplementation if SatO2 is less than 94\%, maintenance of the MBP between $65-70 \mathrm{mmHg}$ (in cases of shock, supply isotonic hydration at $30 \mathrm{ml} / \mathrm{kg}$, proceeding to vasoactive drugs if refractory), protective mechanical ventilation (tidal volume $4-8 \mathrm{~mL} / \mathrm{kg}$, plateau pressure $<30 \mathrm{cmH} 2 \mathrm{O}$ ), intermittent nocturnal sedation for early weaning, prevention of DVT/PE (stimulate ambulation, use of compression tights/intermittent pneumatic compression, low-molecular-weight heparin), prevention of nosocomial infection (pneumonia associated with mechanical ventilation, infections due to catheters), prevention of decubitus ulcers (change of decubitus every $2 \mathrm{~h}$ ) are essential and must be implemented in cases of Covid-19 ${ }^{2,10}$. Upon medical discharge, the patient must be instructed on possible clinical worsening 5-8 days after the onset of symptoms.

Look for epidemiological measures of infection control management. Mild cases should be treated on an outpatient basis, with home isolation, and instructing all household individuals on sanitary practices (the patient must be restricted to the bedroom, with the door closed and well ventilated, fomites must be sanitized with soap and water or alcohol $70^{\circ}$ by the patient, minimal agitation and handling of clothing, frequent 
sanitation of hands by the patient and other household members, quarantine of all household members for 15 days) ${ }^{2}$. Severe cases must be hospitalized in isolation, 2 meters away from other suspected cases, and with the necessary precautions. NIV should be used with caution: although it is effective in preventing the intubation of patients with respiratory distress, it can cause dispersion of droplets. The use of PPE by health professionals (disposable caps and gowns, face shields, gloves, and N95 masks) is indicated, and respiratory masks should be provided to symptomatic patients already in the hospital ${ }^{2,10}$.

Early clinical trials with small samples were promising for the use of hydroxychloroquine + azithromycin and remdesevir (an antiviral drug developed against the Ebola Virus) ${ }^{8,9}$.

Hydroxychloroquine (HQ) and chloroquine (CQ) are immunomodulators implicated in the inhibition of lysosomal activation of antigen-presenting dendritic cells and in the suppression of TRL binding, thus attenuating the production of IL-1, IFN-1, and TNF. The first action would reduce the excessive secretion of cytokines, delaying the overactivation of the immune system triggered by the disease. In addition to this role in modulating the immune response, HCQ and CQ inhibit binding to the receiver and fusion of the membrane, the two main steps necessary for the cell entry by coronaviruses: interfering in the glycosylation of the angiotensin-converting enzyme 2 (ACE2) (the cell receptor of SARS-CoV) and blocking the binding of the virus to the host cell. In addition, they significantly raise the endosomal $\mathrm{pH}$, interrupting the action of proteases and activation of the endosome for virus endocytosis. It is recommended that a dose of $400 \mathrm{mg}$ twice a day of hydroxychloroquine sulfate administered orally, followed by a maintenance dose of $200 \mathrm{mg}$ twice a day for 4 days. Gastrointestinal responses, such as vomiting and diarrhea, are the most common adverse effects of these two drugs. Patients with exposure to CQ exceeding 5 years suffer severe side effects, such as retinopathy, circular defects (bulls-eye maculopathy), and cardiomyopathy. There is no contraindication to HQ during pregnancy. (Figure 1)

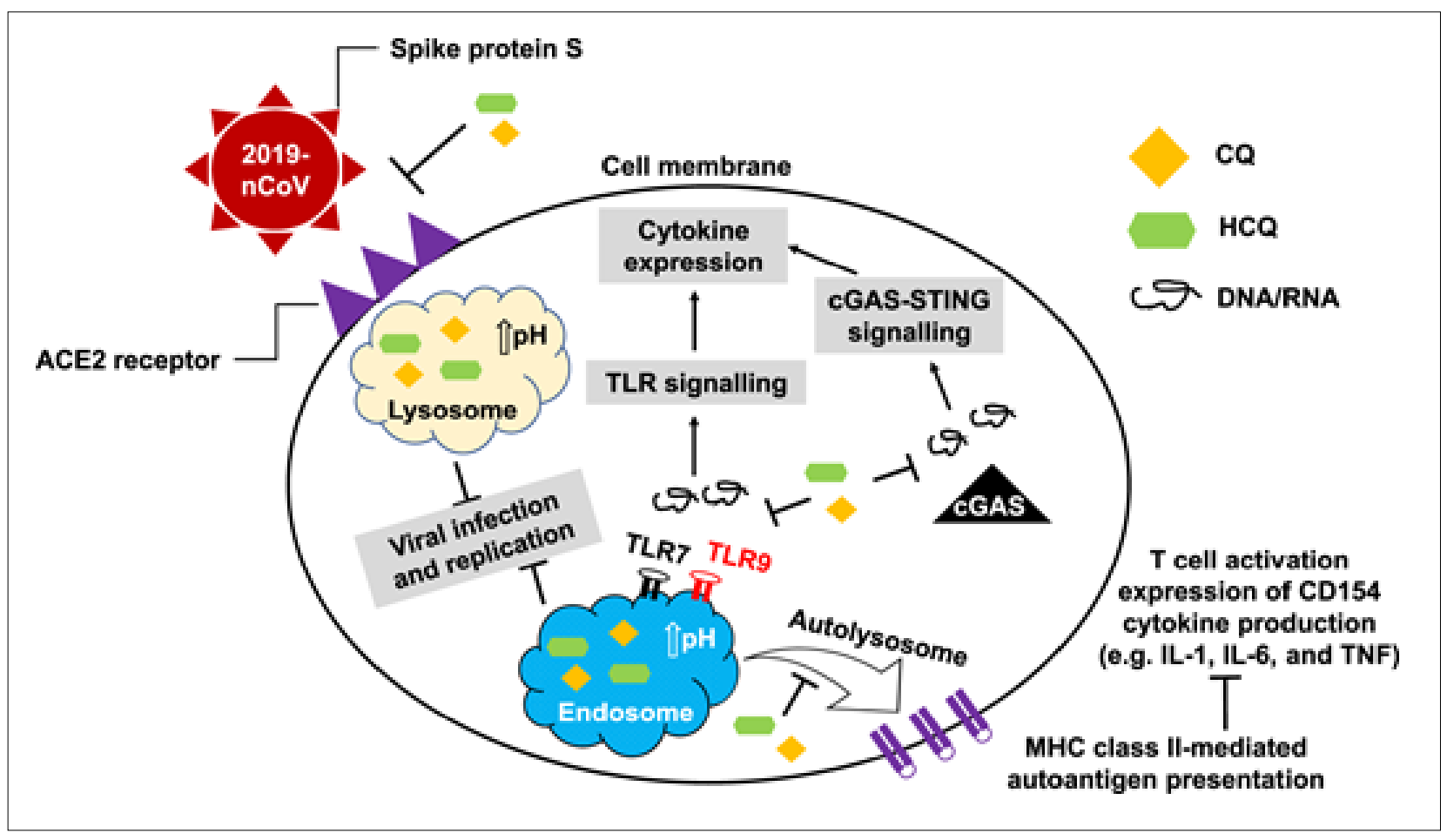

FIGURE $1^{8,9}$. A graphic illustration of the antiviral mechanisms of CQ and HCQ. Both chemicals may interfere in the glycosylation of ACE2 and reduce the efficiency of binding between ACE2 in host cells and spike protein (S) on the surface of the coronavirus. They can also increase the $\mathrm{pH}$ of endosomes and lysosomes, thus preventing the process of binding of the virus with host cells and its subsequent replication. When HCQ enters APCs, it prevents antigen processing and the presentation of autoantigen mediated by class II MHC in T cells. The subsequent activation of T cells and the expression of CD154 and other cytokines are suppressed. In addition, HCQ interrupts the interaction of DNA / RNA with TLRs and the nucleic acid sensor cGAS and, therefore, the transcription of proinflammatory genes cannot be stimulated. As a result, the administration of CQ or $\mathrm{HCQ}$ not only blocks the invasion and replication of coronaviruses but also mitigates the risk of a cytokine storm ${ }^{9}$. 
Remdesevir is a promising drug, along with HQ. An antiviral drug, it has been linked to the reduction of viral load and decreased severity of the condition. A dose of $200 \mathrm{mg}$ in D1, followed by $100 \mathrm{mg} /$ day for 9 days in single daily doses, is recommended ${ }^{3,6}$.

The use of corticosteroids has been associated with a worse clinical outcome and is not recommended. Its use in initial presentations was related to a higher viral load, and its use during the period of severe pneumonia was related to delayed clearance of the viral load, as well as the decompensation of diabetes mellitus and presence of psychosis ${ }^{6,8}$.

However, it should be considered in the presence of septic shock refractory to vasopressors and with suspected adrenal insufficiency ${ }^{11}$.

Measures such as self-quarantine or temperature control at borders should not be very effective since half of the infections are asymptomatic, and $44 \%$ of the patients do not present fever ${ }^{1,5}$. Currently, there is a consensus regarding the closing of schools and restrictions of social gatherings (including the closure of workplaces) to limit population movements and introduce the so-called sanitary cordons (quarantines at a cities or region scale). There is less consensus regarding which measure should be the first to be implemented, in which combination, and when. The World Health Organization recommends universal testing with subsequent isolation of positive asymptomatic patients (effective measure to control the spread of the virus $)^{2,10}$.

The association between the use of ACE inhibitors and increased infectivity and severity of SARS-CoV-2 has also been described; however, it is known that cardiovascular diseases are still the number one cause for deaths worldwide; therefore, it is not advisable to suspend such medication ${ }^{2,5,6,9}$.

\section{DIFFERENTIAL DIAGNOSES IN PEDIATRICS}

Current data indicate that symptomatic pediatric cases are rare, as well as severe cases in individuals without comorbidities younger than 20 years ${ }^{3,6,7}$. Therefore, in the face of a pediatric respiratory syndrome case, one of the differential diagnoses below should be raised:

\section{$\rightarrow$ Acute viral rhinopharyngitis:}

It is the most common infectious disease during childhood (children younger than 5 years usually present from 5 to 8 episodes per year) ${ }^{12}$.
The most common etiologic agents are: rhinovirus, coronavirus, respiratory syncytial virus (RSV), influenza, parainfluenza, coxsackie, and adenovirus. The transmission is by droplets and direct contact with the mucous membranes, and the incubation period is of 2-5 days ${ }^{12}$. The affected individual presents a risk of contagion in the one-day period before the onset of symptoms and two days after it.

The clinical presentation lasts from 5 to 7 days and includes rhinorrhea, nasal obstruction, dry coughing, sneezing, pharyngitis, and fever of variable intensity. There may be hyperemia of the tympanic membrane, changes in sleep, and irritability in infants. The adenovirus and RSV may generate lower airway infection (leading to tachypnea, retractions, and grunting). The influenza virus is implicated in a more severe clinical presentation, with diarrhea, abdominal pain, prostration, high fever, and myalgia, which puts the clinical presentation of a common cold (coryza, nasal obstruction, cough, and pharyngitis) in the background. Both RSV and rhinovirus can trigger asthma episodes. There may be complications with acute otitis and sinusitis due to the obstruction of the Ostia of the paranasal sinuses and eustachian tube secondary to the inflammatory process or indiscriminate use of decongestants ${ }^{12}$.

The diagnosis is clinical and should be differentiated from hepatitis A (onset of jaundice, increased direct bilirubin and transaminases), measles (intense cough, conjunctivitis with photophobia, exanthema, and enanthema of Koplik), pertussis (severe cough, and may cause vomiting and dyspnea, duration of 6 to 10 weeks, absence of vaccination), rhinitis (ARDS caused by winter, positive family history and personal history of atopy, remission after use of nasal corticosteroids), streptococcal pharyngitis, and mononucleosis (both with intense hyperemia of the oropharynx, petechiae on the palate, hypertrophy of the tonsils and purulent plates). The detection of the virus is unnecessary.

The treatment consists of rest during the febrile period, nasal instillation of isotonic saline solution (3-5 mL in each nostril every 2 hours), and antipyretic medication. In adults with influenza $\mathrm{A}$, one can resort to amantadine $200 \mathrm{mg}$ every $24 \mathrm{~h}$ (pre-contact prophylaxis with 70-80\% of effectiveness, equally effective treatment with a reduction of the symptomatic period). In children older than 12 years or weighing over $40 \mathrm{~kg}$ and adults with suspicion of influenza type A or B, oseltamivir 75 
mg can be used every $12 \mathrm{~h}$ for 5 days (pre-contact prophylaxis with $92 \%$ efficiency, reduces the severity and duration of symptoms, can be used in children over one year). The use of probiotics and vitamin $\mathrm{C}$ in high doses (>1g/day) has proven effective in the prevention of common colds in athletes, as well as in the reduction by $20 \%$ of the duration of the condition in children. Caretakers should be instructed on the need for hand hygiene at home and to return in case of clinical worsening. ${ }^{12}$

\section{$\rightarrow$ Acute sinusitis}

Defined as a bacterial infection of the paranasal sinuses, with a duration of fewer than 30 days. Acute sinusitis is rare in small children since the maxillary and ethmoidal sinuses are reduced before the age of two years, and the frontal and ethmoidal sinuses develop from the age of 4 years.

The most frequent etiological agents are Moraxella catarrhalis, Hamophilus influenza, and Streptococcus pneumoniae. $^{12}$

Acute sinusitis is suspected when there is the persistence of ARDS exceeding 10 days or recurrence after clinical improvement. The symptoms include nasal obstruction, purulent rhinorrhea, halitosis, coughing with worsening at night, fever, and frontal tension headache (may also present as pain in teeth). There may be osteomyelitis, periorbital cellulitis (a sign of inflammation on the ethmoid bones), meningitis, thrombosis of the cavernous sinus, and brain abscess.

The diagnosis is clinical, and an x-ray of the paranasal sinuses is usually unnecessary. It must be differentiated from adenoiditis (snoring, epistaxis, acute otitis media) and nasal foreign body (obstruction and asymmetrical rhinorrhea, history of foreign body insertion). It may be necessary to have a specialized assessment if sinusitis lasts for over 90 days or in case of recurrent sinusitis. It may be necessary to have a computed tomography of the skull in refractory cases or in case of suspected complications.

The treatment consists of rest, antipyretics, nasal instillation of isotonic saline solution every $2 \mathrm{~h}$, topical or systemic corticosteroids (in case of a history of asthma), and antimicrobial agents. The first choice is amoxicillin clavulanate $875+125 \mathrm{mg}$ every $12 \mathrm{~h}$ for 7 days (or 10 days in case of resistance factors). Other options are cefuroxime, clarithromycin, or azithromycin. In the absence of a response after $48 \mathrm{~h}$, consider doubling the dose or changing the medication. Instructions to avoid decongestants and diving during periods of ARDS, avoid smoking (active and passive), and proper treatment of allergic rhinitis. $^{12}$

Children with allergic rhinitis can present chronic or repetition sinusitis.

\section{$\rightarrow$ Streptococcal pharyngitis (SAP)}

SAP is an acute infection of the oropharynx by Streptococcus pyogenes (group A beta-hemolytic). It is transmitted via droplets, or direct contact with patients presents incubation of two to five days and represents 15\% of ARDS. ${ }^{12}$

The most common clinical presentation is high fever, odynophagia with sudden onset, pharyngeal hyperemia, hypertrophy of the tonsils and tonsillar exudate, associated or not with prostration, cervical adenopathy, vomiting, and abdominal pain. It can complicate with cervical lymph node abscesses, acute otitis media, post-streptococcal glomerulonephritis, reactive arthritis, rheumatic fever, and sepsis.

The diagnosis is clinical, and a quick test can be used. It must be differentiated from scarlet fever (strawberry tongue, exanthema with signs of Pastia - increase of the flexural exanthema, and Filatov - perioral pallor), viral pharyngitis (coryza, absence tonsil hypertrophy, and exudate), diphtheria (predominant diarrhea, grayish-white plates in the oropharynx that may invade the uvula) and infectious mononucleosis (generalized adenopathy, exanthema after the use antimicrobial agents).

The treatment is based on rest, infusion of warm saline solution in the oropharynx, antipyretics, and antibiotics (the drug of choice is benzathine penicillin G 600 thousand or 1.2 million IU IM single dose, for $<27 \mathrm{~kg}$ and $>27 \mathrm{~kg}$, respectively). The treatment is less painful if a heated solution used for dilution. In the case of allergy to penicillin, the drug of choice is erythromycin estolate $40 \mathrm{mg} / \mathrm{kg} /$ day in 2-3 administrations. ${ }^{12}$ Instruct the patient to return in case of dysphagia and muffled/nasalized voice (tonsillar abscess), dyspnea, exanthema, or clinical worsening. Instruct to be absent from nursery/school and work activities for $48 \mathrm{~h}$ after starting the treatment.

\section{$\rightarrow$ Viral croup}

This is subglottic laryngitis, a viral infection with a variable degree of congestion and obstruction of the airways. It is often caused by RSV and parainfluenza 

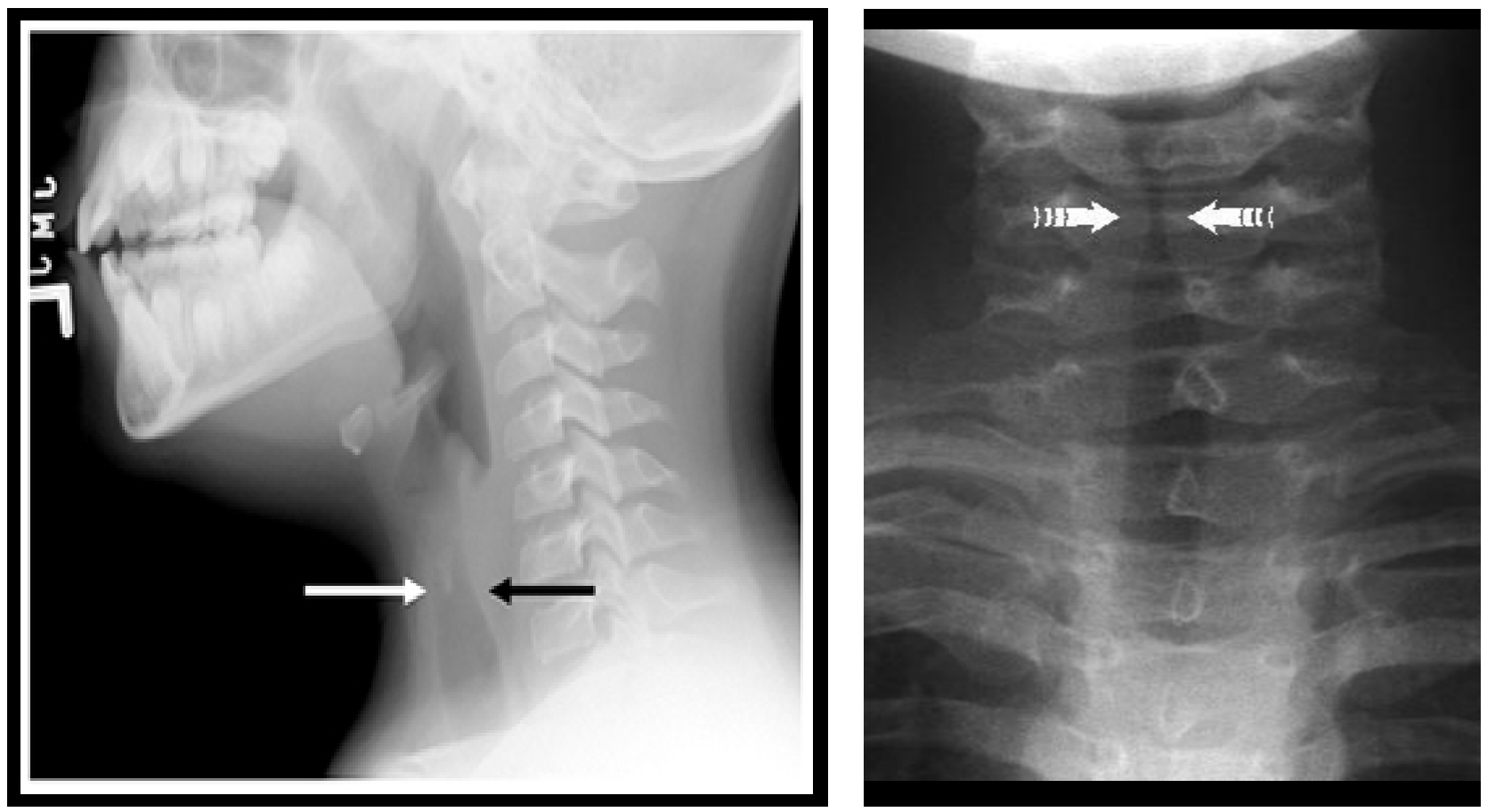

FIGURE 2. CERVICAL RADIOGRAPHY SUGGESTIVE OF VIRAL CROUP. IMAGE BY JOHN MCBRIDE, MD

I and II, presents a natural history of partial obstruction of the airways for 2-3 days, with remission after 5 days. $^{12}$

The clinical manifestations include prodromes (coryza, dry cough, nasal obstruction, and fever) and laryngitis (hoarse cough, dysphonia/aphonia, and respiratory stridor). There may be signs of respiratory failure (nasal flaring, subcostal retraction, tachypnea, cyanosis/paleness) and can evolve to airway obstruction and death.

The diagnosis is clinical and can be aided by radiography (laryngeal narrowing with pencil-point sign). It must be differentiated from a foreign body (sudden onset of airway obstruction, with cyanosis and cough), a congenital malformation of the airway (repeat laryngitis), spasmodic laryngitis (absence of prodromes, nocturnal onset, spontaneous regression, personal history of GERD, and improvement with humidification) and allergic laryngeal edema (history of exposure to allergens or drugs, presence of angioedema and other stigmata of anaphylaxis).

The treatment is based on the humidification of the environment and hydration, as well as symptomatic treatment. In severe cases (progressive or at rest stridor, signs of respiratory failure, toxemia), use inhaled corticosteroids and consider tracheal intubation. ${ }^{12}$

\section{RESUMO}

INTRODUÇão: A pandemia de covid-19 decretada pela OMS suscita maior conhecimento acerca da doença.

EPIDEMIOLOGIA: A infecção atingiu a marca de 350.000 pacientes em 33 países e levantou como fatores de risco a presença de comorbidades e a idade avançada.

TRANSMISSIBILIDADE: A transmissibilidade calculada até o momento é similar à da epidemia de H1N1, contudo, com taxa de mortalidade inferior.

FISIOPATOLOGIA: O vírus SARS-CoV-2, da família Coronaviridae, tem capacidade de invasão celular através da enzima conversora de angiotensina 2 presente no epitélio respiratório inferior e nas células da mucosa do intestino delgado.

MANIFESTAÇÕES CLíNICAS: A apresentação pode ser dividida em leve (febre, fadiga, tosse, mialgia e escarro) e grave (cianose, dispneia, taquipneia, dor torácica, hipoxemia e necessidade de ventilação mecânica) e tem mortalidade estimada de pouco mais de $2 \%$.

DIAGNÓSTICO: Dá-se pela detecção da carga viral no PCR-TR de pacientes com alta suspeição clínica.

TRATAMENTO: Baseado em medidas de suporte e de controle de infecção. Em casos graves, uso de medicamentos como hidroxicloroquina e azitromicina ou remdesivir podem ser promissores. Evitar o uso de corticosteroides. Não há evidências suficientes para abster-se do uso de ibuprofeno e IECAs/BRAs.

Palavras-Chave: Coronavírus. Covid-19. Pandemia. Atualização. 


\section{REFERENCES}

1. Chen J. Pathogenicity and transmissibility of 2019-nCoV - A quick overview and comparison with other emerging viruses. Microbes and Infection Volume 22, Issue 2, March 2020, Pages 69-71. https://doi.org/10.1016/j. micinf.2020.01.004

2. Organização Mundial da Saúde. Prevenção e controle de infecção durante os cuidados de saúde quando houver suspeita de nova infecção por coronavírus (nCoV). 25 de janeiro de 2020. https://www.who.int/publications-detail/ infection-prevention-and-control-during-health-care-when-novel-coronavirus-(ncov)-infection-is-suspected-20200125.

3. Yang $X, Y u Y, X u$ J, et al. Curso clínico e resultados de pacientes críticos com pneumonia por SARS-CoV-2 em Wuhan, China. Lancet Respir Med . 2020. S2213-2600 (20) 30079-5

4. Wang $\mathrm{D}, \mathrm{Hu} \mathrm{B}, \mathrm{Hu} \mathrm{C}$, et al. Características clínicas de 138 pacientes hospitalizados com 2019 nova pneumonia infectada por coronavírus em Wuhan, China. JAMA. Publicado online em 7 de fevereiro de 2020. doi: 10.1001 / jama.2020.1585

5. Burke RM, Midgley CM, Dratch A, et al. Monitoramento ativo de pessoas expostas a pacientes com COVID-19 confirmado - Estados Unidos, janeiro-fevereiro de 2020. MMWR Morb Mortal Wkly Rep 2020; 69: 245.

6. Tang A, Tong ZD, Wang HL, et al. Detecção de novo coronavírus por
RT-PCR em amostras de fezes de Criança Assintomática, China. Emerg Infect Dis 2020; 26.

7. Lai CC, Liu YH, Wang CY, Wang YH, Hsueh SC, Yen MY, Ko WC, Hsueh PR. Estado portador assintomático, doença respiratória aguda e pneumonia devido a coronavírus 2 da síndrome respiratória aguda grave (SARS-CoV-2): fatos e mitos. I Microbiol Immunol Infect . 20204 de março. (20) 30040-2.. PMID: 32173241

8. Yao X, Ye F, Zhang, M. Atividade antiviral in vitro e projeção de projeto de dosagem otimizada de hidroxicloroquina para o tratamento do coronavírus 2 da síndrome respiratória aguda grave (SARS-CoV-2). Clin Infect Dis . 2020 9 de março. PMID: 32150618

9. Dan Z, Sheng-Ming D, Qiang T. COVID-19: uma recomendação para examinar o efeito da hidroxicloroquina na prevenção de infecção e progressão. Journal of Antimicrobial Chemotherapy. 20 de março de 2020. https://doi. org/10.1093/jac/dkaa114.

10. Ministério da Saúde. Protocolo de Manejo Clínico para o Novo Coronavírus (2019-nCoV). Ministério da Saúde. Brasília - DF 2020.

11. Goldman L; Ausiello D. Cecil Medicina Interna. 24. ed. SaundersElsevier, 2012.

12. Tratado de Pediatria - Richard E. Behrman, Hal B. Jenson, Robert Kliegman. 19a. Edição. Elsevier. 2013. 